CYP を阻害するフラノクマリン, ベンゾフラン及び クマリン誘導体の合成と CYP 阻害メカニズムの解明

\author{
山口由基
}

\title{
Synthesis of Furanocoumarin, Benzofuran and Coumarin Derivatives Possessing an Inhibitory Effect on Human CYP, and Elucidation of the Inhibitory Mechanism
}

\author{
Yuki Yamaguchi \\ School of Pharmaceutical Sciences, Health Sciences University of Hokkaido; \\ 1757 Kanazawa, Tobetsu-cho, Ishikari-gun, Hokkaido 061-0293, Japan.
}

(Received June 5, 2017)

\begin{abstract}
Grapefruit juice (GFJ) consumption has been shown to increase the bioavailability of certain orally administered drugs. The furanocoumarin derivatives Paradisin A and bergamottin, which are present in GFJ, are potent mechanismbased inhibitors of CYP3A4. The primary aim of this work was to synthesize a series of furanocoumarin derivatives with a view to determining the relationship between the structure of the inhibitors and their inhibitory CYP3A4 activity. Furanocoumarin derivatives that were more stable and accessible than the furanocoumarin derivatives in GFJ were prepared, and their ability to inhibit CYP3A4 was examined. Synthesized furanocoumarin monomers showed strong mechanism-based inhibition of CYP3A4. The furanocoumarin dimers are also mechanism-based inhibitors of CYP3A4. These monomers and dimers are more potent inhibitors of CYP3A4 than bergamottin and Paradisin A, respectively.
\end{abstract}

Key words_ - furanocoumarin; bergapten; CYP3A4; grapefruit juice

\section{はじめに}

シトクロム P450（CYP） は，1950-1960 年代に 薬物代謝酵素として認識されて以降，分子種の同定 やそれにより代謝される化合物の探索，及びその活 性を誘導又は阻害する化合物等に関する多くの研究 がなされている. 1) 代謝研究では，医薬品に代表さ れる外因性物質だけではなく生体内因性物質等様々 な物質を代謝することが明らかとされてきた。これ らの研究を総合すると，“CYP を阻害する”ことは 単に薬物相互作用の原因となるだけではなく, CYP 分子種によっては医薬品開発につなげること ができる，筆者はこれまでに，化学合成したフラノ クマリン, ベンゾフラン, クマリン等の誘導体と CYP2A6, 3A4, 19 （アロマターゼ）阻害に関する 構造活性相関研究を行っている。本稿では，フラノ クマリン誘導体と CYP3A4 阻害について述べる.

北海道医療大学薬学部（T061-0293 北海道石狩郡当別 町金沢 1757)

e-mail: y.yamagu@hoku-iryo-u.ac.jp

本総説は, 平成 28 年度日本薬学会北海道支部奨励賞の

受賞を記念して記述したものである.
CYP3A4 は薬物代謝の中心的な役割を果たして いる。現在では，Fig. 1 に示した 1 及び 2 等グレー プフルーツジュース（GFJ）中のフラノクマリン類 が CYP3A4 活性を阻害するため，併用薬の体内動 態に影響を与えることは，医療関係者にとつて周知 の事実であり，CYP3A4 により代謝される多くの 薬物とGFJ との相互作用が解明されてきた. ${ }^{2,3)} し$ かし, GFJ の生産メーカーやロット毎にフラノク マリン類の含有量が大きく異なるため, 市販の GFJ を用いて相互作用を定量的に解析することは 困難である. ${ }^{4,5)}$ したがって，相互作用を定量的に解 析するにはフラノクマリン誘導体を用いた研究が不 可欠となる。しかし，GFJ に含まれるフラノクマ リン類のうち，標品として市販されているのは 2 の みであり，他のフラノクマリン誘導体は GFJ から の単離が必要となるが, これら誘導体は GFJ 中に ごくわずかしか含まれていない. ${ }^{4,6}$ そこで，薬物相 互作用の定量的な解析を目的とし, 化学合成したフ ラノクマリン誘導体とCYP3A4 阻害能との構造活 性相関研究を行つた。 

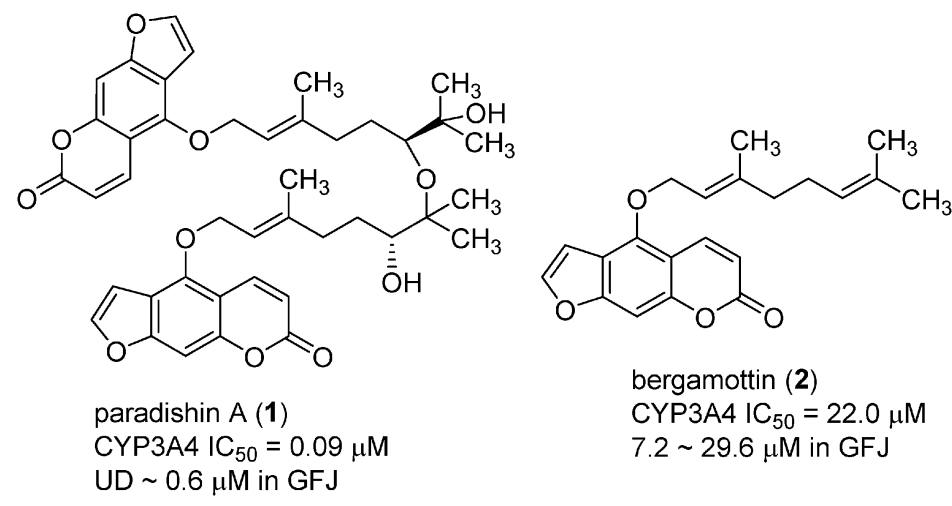

Fig. 1. Paradishin A (1) and Bergamottin (2)

\section{フラノクマリン誘導体の合成}

天然に存在するフラノクマリン誘導体に関する研 究から，フラノクマリン骨格が CYP3A4 の阻害に 不可欠な構造であると考えられている. 7,8) そこで, フラノクマリン誘導体単量体では側鎖, 二量体では 2 つのフラノクマリン環をつないでいるリンカーを 変換した誘導体（Fig. 2) をターゲットとした.

ターゲットとした誘導体は，4-又は 9-ヒドロキシ フラノクマリン $(\mathbf{3}, \mathbf{8})$ のアルキル化によって合成 可能と考えた。 ヒドロキシフラノクマリンはアルコ キシフラノクマリンの脱アルキル化により調製可能 である.アルコキシフラノクマリンのうち 9-メト キシフラノクマリン（9）は市販されていたため, 購入し反応に用いた。4-メトキシフラノクマリン （4）は，市販されているものの高価であり，既報の 合成法では収率が低かったため, ${ }^{9)}$ 新規合成経路の 開発を行った。

Reisch らに従い合成した 18 ${ }^{10)}$ のヒドロキシ基を 2-ブロモアセトアルデヒドジメチルアセタールを用 いてアルキル化し19 とした（Scheme 1)。それに， 三フッ化ホウ素・ジエチルエーテル錯体11)を作用さ せてアルデヒドの脱保護と同時にフラン環を構築し たところ，2 種類の生成物を得た．結果，ベルガプ テン（4）の収率は 9\%であり，8位で閉環したイソ ベルガプテン（21）が $43 \%$ 生成した。 そこで， 21 の副生を避けるために $\mathbf{1 8}$ の 8 位をヨウ素で封鎖 し, ${ }^{12)}$ 位置選択的なフラン環の構築を試みた (Scheme 2)．化合物 22 のヒドロキシ基と 2-ブロモ アセトアルデヒドジメチルアセタールとの反応を試 みたが，ヨウ素の立体障害のため反応は進行しな かった。そこで，より反応性の高い臭化アリルによ

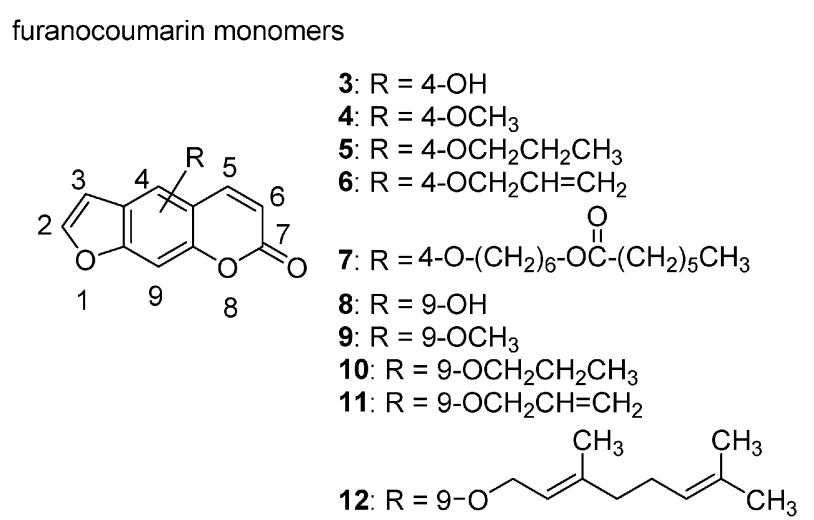

furanocoumarin dimers

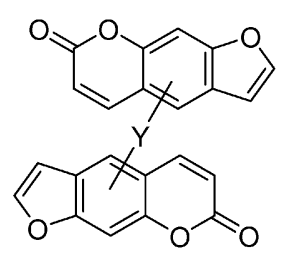

13: $\mathrm{Y}=4,4 \mathrm{\prime}-\mathrm{O}-\left(\mathrm{CH}_{2}\right)_{5}-\mathrm{O}$ -

14: $\mathrm{Y}=4,9^{\prime}-\mathrm{O}-\left(\mathrm{CH}_{2}\right)_{5}-\mathrm{O}-$

15: $\mathrm{Y}=9,9 '-\mathrm{O}-\left(\mathrm{CH}_{2}\right)_{5}-\mathrm{O}-$

16: $\mathrm{Y}=9,9^{\prime}-\mathrm{O}-\left(\mathrm{CH}_{2}\right)_{8}-\mathrm{O}-$

Fig. 2. Target Compounds

り 7 位のヒドロキシ基をアリル化後, 23 の側鎖不 飽和結合の酸化的開裂によりアルデヒド $\mathbf{2 4}$ へ変 換した. ${ }^{13)}$ 次に，19 と同様の閉環反応を行い，フラ ノクマリン環を構築して 25 とした後，封鎖基をは ずしてベルガプテン（4）を得ることができた．続 いて，三臭化ホウ素により脱メチル化した 3 をハロ アルコールによってアルキル化して 26 へ導いてか ら，カプロイルクロリドを作用させることで 4 位置 換フラノクマリン誘導体 7 を合成した.

4,9 位置換フラノクマリン二量体は，市販のメト キサレン（9）から調製した 9-ヒドロキシフラノク マリン $(\mathbf{8})^{14)}$ に対して過剩量の 1,5-ジブロモペンタ ンを作用させてモノアルキル体 $\mathbf{2 7}$ に変換後, $\mathbf{3}$ と 
<smiles>COc1cc(OCC(OC)Oc2cc(OC)c3ccc(=O)oc3c2)cc2oc(=O)ccc12</smiles><smiles>COc1cc(OCC=O)cc2oc(=O)ccc12</smiles>

Scheme 1. Synthesis of Bergapten (4)

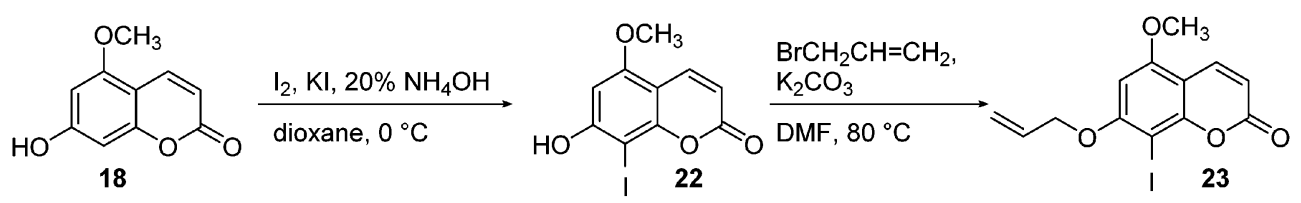

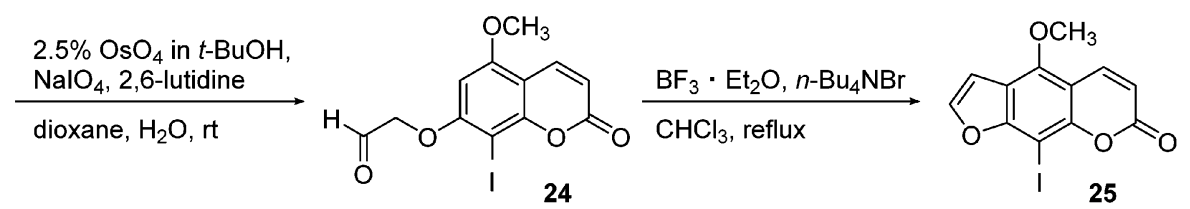

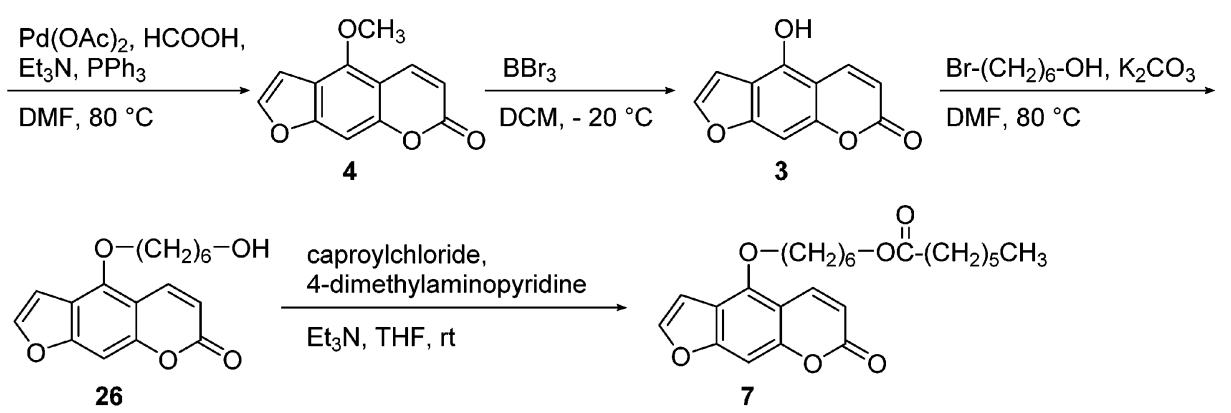

Scheme 2. Synthesis of 4-Alkoxy Furanocoumarin Monomer 7

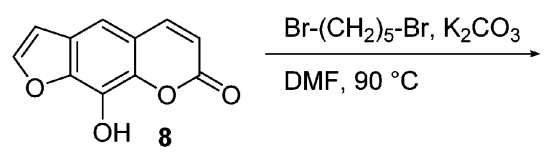<smiles>CCCOc1c2occc2cc2ccc(=O)oc12</smiles><smiles>CC(C)(C)OC(=O)CO</smiles><smiles>COc1c2ccoc2cc2oc(=O)ccc12</smiles>

14

Scheme 3. Synthesis of 4,9'-Substituted Furanocoumarin Dimer 14 
Table 1. Synthesis of Furanocoumarin Monomers<smiles></smiles>
R-X, Base Solvent, Temperature<smiles>[R]Oc1c2cc3oc(=O)ccc3c1C=CO2</smiles>

\begin{tabular}{cccccccc}
\hline \hline Substrate & $\mathrm{R}$ & $\mathrm{X}$ & Base & Solvent & Temperature & Products & Yield (\%) \\
\hline $\mathbf{3}$ & geranyl & $\mathrm{Cl}$ & $\mathrm{Cs}_{2} \mathrm{CO}_{3}$ & $\mathrm{CH}_{3} \mathrm{CN}$ & reflux & $\mathbf{2}$ & 27 \\
$\mathbf{3}$ & propyl & $\mathrm{I}$ & $\mathrm{Cs}_{2} \mathrm{CO}_{3}$ & $\mathrm{DMF}$ & $120^{\circ} \mathrm{C}$ & $\mathbf{5}$ & 37 \\
$\mathbf{3}$ & allyl & $\mathrm{Br}$ & $\mathrm{Cs}_{2} \mathrm{CO}_{3}$ & $\mathrm{DMF}$ & $120^{\circ} \mathrm{C}$ & $\mathbf{6}$ & 55 \\
$\mathbf{8}$ & propyl & $\mathrm{Br}$ & $\mathrm{Cs}_{2} \mathrm{CO}_{3}$ & $\mathrm{CH}_{3} \mathrm{CN}$ & reflux & $\mathbf{1 0}$ & quant. \\
$\mathbf{8}$ & allyl & $\mathrm{Br}$ & $\mathrm{K}_{2} \mathrm{CO}_{3}$ & acetone & reflux & $\mathbf{1 1}$ & 73 \\
$\mathbf{8}$ & geranyl & $\mathrm{Cl}$ & $\mathrm{Cs}_{2} \mathrm{CO}_{3}$ & $\mathrm{CH}_{3} \mathrm{CN}$ & reflux & $\mathbf{1 2}$ & 66 \\
\hline
\end{tabular}

Table 2. Synthesis of Furanocoumarin Dimers

\begin{tabular}{ccccccc}
\hline Substrate & $n$ & Base & Solvent & Temperature & Products & Yield (\%) \\
\hline $\mathbf{3}$ & 5 & $\mathrm{Cs}_{2} \mathrm{CO}_{3}$ & $\mathrm{CH}_{3} \mathrm{CN}$ & reflux & $\mathbf{1 3}$ & 72 \\
$\mathbf{8}$ & 5 & $\mathrm{~K}_{2} \mathrm{CO}_{3}$ & $\mathrm{DMF}$ & $120^{\circ} \mathrm{C}$ & $\mathbf{1 5}$ & 69 \\
$\mathbf{8}$ & 8 & $\mathrm{~K}_{2} \mathrm{CO}_{3}$ & $\mathrm{DMF}$ & $120^{\circ} \mathrm{C}$ & $\mathbf{1 6}$ & 87 \\
$\mathbf{8}$ & 10 & $\mathrm{~K}_{2} \mathrm{CO}_{3}$ & $\mathrm{DMF}$ & $120^{\circ} \mathrm{C}$ & $\mathbf{1 7}$ & 89 \\
\hline
\end{tabular}

縮合させた（Scheme 3）。フラノクマリン単量体 2, 5，6，10-12 及び二量体 13，15-17 も同様に，3 又は 8 と相当するハロゲン化アルキル又はジブロモアル カンとの縮合により合成した（Tables 1 and 2). 4-ヒドロキシ体 $\mathbf{3}$ に比べて，9-ヒドロキシ体 8 は反 応性が高く，より穏やかな条件かつ比較的高収率で 目的化合物を得ることができた。

\section{CYP3A4 阻害能の測定}

BD Corning 社より購入したバキュロウイルス発 現系ヒト CYP3A4 を用いて, テストステロンの $6 \beta$-ヒ ドロキシ化反応7) に対する誘導体 2-17 の $\mathrm{IC}_{50}$ 值を 測定後(Table 3), mechanism-based inhibition (MBI) の有無を測定した（Fig. 3)。

CYP3A4 活性は，基質や酵素の種類によって変 化するとされているため, ${ }^{15-17)}$ 合成した 2 を測定し たところ $\mathrm{IC}_{50}$ 值は $0.35 \mu \mathrm{M}$ を示した（Table 3)。こ れまでにヒトプールドミクロソームを用いて測定さ れた值 $(22 \mu \mathrm{M})^{7)}$ とは異なるものであったことか ら，本稿ではこの值を用いて比較を行った。なお， $\mathrm{IC}_{50}$ 值が $10 \mu \mathrm{M}$ 以上のものについては> $>10 \mu \mathrm{M}$ と記 す。フラノクマリン単量体 2-12 の $\mathrm{IC}_{50}$ 值は, $0.18->10 \mu \mathrm{M}$ であり，4 位置換体 2-7 と9 位置換体
Table 3. $\mathrm{IC}_{50}$ Values of Furanocoumarin Derivatives on Testosterone $6 \beta$-Hydroxylation

\begin{tabular}{cc}
\hline \hline Compounds & $\mathrm{IC}_{50}(\mu \mathrm{M})$ \\
\hline $\mathbf{2}$ & 0.35 \\
$\mathbf{3}$ & 10 \\
$\mathbf{4}$ & 1.51 \\
$\mathbf{5}$ & 0.54 \\
$\mathbf{6}$ & 0.43 \\
$\mathbf{7}$ & 0.08 \\
$\mathbf{8}$ & 10 \\
$\mathbf{9}$ & 5.46 \\
$\mathbf{1 0}$ & 0.48 \\
$\mathbf{1 1}$ & 0.76 \\
$\mathbf{1 2}$ & 0.18 \\
$\mathbf{1 3}$ & 0.15 \\
$\mathbf{1 4}$ & 0.03 \\
$\mathbf{1 5}$ & 0.03 \\
$\mathbf{1 6}$ & 0.04 \\
$\mathbf{1 7}$ & 0.05 \\
\hline
\end{tabular}

8-12 の比較から，置換位置による違いはみられな かった。 したがって，GFJ 含有フラノクマリン類 のように 4 位置換体であることは必須ではない可能 性が示唆された。活性は側鎖構造に応じて変化し, ヒドロキシ体 3,8 及びメトキシ体 4,9 ではほとん 


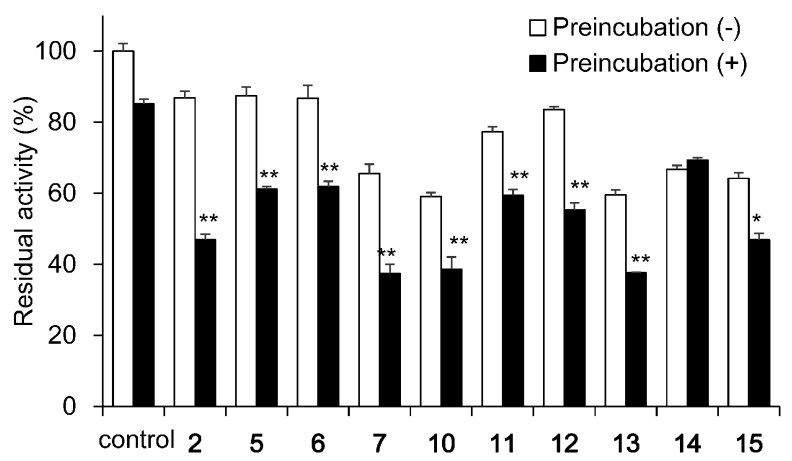

Fig. 3. Effects of Preincubation with Inhibitors on Testosterone $6 \beta$-Hydroxylation

Each column represents mean \pm S.D. $(n=3)$. Furanocoumarin derivatives were studied at $0.005-0.2 \mu \mathrm{M} .{ }^{*} p<0.01,{ }^{* *} p<0.001$ : Significantly different from peak area ratio of preincubation $(-)$.

ぞ阻害しないのに対して，嵩高い側鎖の誘導体 2, 5-7, 10-12 では強力になる傾向を示した。炭素数が 3 以上の側鎖を有する誘導体の阻害能が 2 と同程度 であったことから，ゲラニル基のような複雑な側鎖 は必須ではないと推察された。二量体 13-17では 0.03-0.15 $\mu \mathrm{M}$ を示し，リンカーの炭素鎖長を伸長さ せても活性に大きな変化はなく，ほとんどの誘導体 がパラジシン A $(1,0.09 \mu \mathrm{M})^{7)}$ と同程度若しくは強 力な阻害剂であることが示唆された。 4,4'位置換体 に比べて 4,9'又は 9,9'位置換体で強力になる傾向を 示した。したがって，19ように嵩高いリンカー構 造は阻害能の発現に必須ではないと考えられた。ま た，カプロン酸エステル体 7 は単量体でありながら も二量体に匹敵する強力な阻害剂であることが明ら かとなった。

MBI とは阻害剂の代謝物による不可逆阻害であ り, ベルガモチン (2) 等 GFJ 含有のフラノクマリ ン誘導体は MBI を示すと報告されている. ${ }^{7,18)}$ そこ で，MBIの発現メカニズムを解明するために， CYP3A4 を阻害した誘導体 2, 5-7, 10-15 に関して MBI の有無を測定することとした。阻害剂を NADPH 存在下で CYP3A4 とともに 10 分プレイン キュベートして阻害剤の代謝物を生成させた場合 [プレインキュベーション $(+)]$ と，プレインキュ ベートしない場合 [プレインキュベーション $(-)]$ の酵素活性を比較した。プレインキュベーション (一) 時とプレインキュベーション $(+)$ 時の活性 值の差が大きいと，阻害様式に MBI を有する. ${ }^{19)}$ なお，阻害剤濃度はプレインキュベーション（一) 時の残存活性が 60-80\%となるようにした.
はじめに，2 $(0.05 \mu \mathrm{M})$ による CYP3A4 に対す る MBI の有無を測定したところ，プレインキュ ベーション (一) 時の残存活性はコントロール： 100\%, 2: 87\%，プレインキュベーション $(+)$ 時 の残存活性はコントロール：85\%, 2: 47\%であった (Fig. 3)。したがって, 残存活性の差はコントロー ル：15\%, 2: 40\%となる.コントロールと比較して, 2 の残存活性がプレインキュベーションにより有意 に減少したことから MBI を有すると判断した。測 定を行った誘導体中, 14 以外の誘導体ではプレイ ンキュベーションにより阻害能が 17-28\%増大し, 阻害様式に MBI を有することが明らかとなった. 4,4'置換体 13 及び 9,9'置換体 $\mathbf{1 5}$ で MBI を示し, 4,9'置換体 14 でのみ MBI を示さなかったことか ら，フラノクマリン二量体では 2 つのラノクマリ ン環とリンカーとの置換位置が MBI の発現に影響 を与えると推察される.

$\mathrm{IC}_{50}$ 值及び $\mathrm{MBI}$ の測定より，4 位又は 9 位に炭 素数 3 以上の側鎖を有するフラノクマリン単量体 5, 6, 10-12 は 2 の等価体であると考えられる。さ らに，フラノクマリン二量体 13，15-17 は，1 の等 価体としての可能性を示唆した. 加えて, カプロン 酸エステル誘導体 7 は，単量体でありながらも MBI を有する非常に強力な阻害剤であり，1 並び に 2 の等価体としての働きが期待される.

\section{おわりに}

化学合成したフラノクマリン誘導体と CYP3A4 阻害能との構造活性相関研究の結果, フラノクマリ ン類の強力な阻害作用には MBI の有無が影響を与 えることを明らかとした。CYP 阻害剤の構造活性 相関研究により薬物相互作用や医薬品開発が発展す ることを期待している.

謝辞本稿で紹介させて頂いた研究は, 北海道 医療大学で行われたものである。ご留意なるご指導 ご鞭撻を賜りました北海道医療大学薬学部 小田和 明特任教授，和田啓爾教授，吉村照毅教授並びに西 園直純准教授に深謝致します。

利益相反＼cjkstart開示すべき利益相反はない.

\section{REFERENCES}

1) Rendic S., Di Carlo F. J., Drug Metab. Rev., 
29, 413-580 (1997).

2) Sawada Y., "Kusuri to Shoku no Sougosayou,', Vol. 1, Medicine and Drug Journal Co., Ltd., Osaka, 2005.

3) Dahan A., Altman H., Eur. J. Clin. Nutr., 58, 1-9 (2004).

4) Guo L. Q., Fukuda K., Ohta T., Yamazoe Y., Drug Metab. Dispos., 28, 766-771 (2000).

5) De Castro W. V., Mertens-Talcott S., Rubner A., Butterweck V., Derendorf H., J. Agric. Food Chem., 54, 249-255 (2006).

6) Ohta T., Nagahashi M., Hosoi S., Tsukamoto S., Bioorg. Med. Chem., 10, 969-973 (2002).

7) Guo L. Q., Taniguchi M., Xiao Y. Q., Baba K., Ohta T., Yamazoe Y., Jpn. J. Pharmacol., 82, 122-129 (2000).

8) Wangensteen H., Molden E., Christensen H., Malterud K. E., Eur. J. Clin. Pharmacol., 58, 663-668 (2003).

9) Howell W. N., Robertson A., J. Chem. Soc., 293-294 (1937).

10) Reisch J., Wickramasinghe A., Kumar V., Monatsh. Chem., 119, 1333-1339 (1988).

11) Ahluwalia V. K., Bhat K., Prakash C., Singh
R. P., Indian J. Chem., Sect. B, 20B, 23-24 (1981).

12) Reisch J., Wickramasinghe A., Wickremaratne D. B. M., Liebigs Ann. Chem., 209-210 (1990).

13) Taylor R. E., Chen Y., Beatty A., Myles D. C., Zhou Y., J. Am. Chem. Soc., 125, 26-27 (2003).

14) McOmie J. F. W., Watts M. L., West D. E., Tetrahedron, 24, 2289-2292 (1968).

15) Kenworthy K. E., Bloomer J. C., Clarke S. E., Houston J. B., Br. J. Clin. Pharmacol., 48, 716-727 (1999).

16) Stresser D. M., Blanchard A. P., Turner S. D., Erve J. C. L., Dandeneau A. A., Miller V. P., Crespi C. L., Drug Metab. Dispos., 28, 1440-1448 (2000).

17) Lu P., Lin Y., Rodrigues A. D., Rushmore T. H., Baillie T. A., Shou M., Drug Metab. Dispos., 29, 1473-1479 (2001).

18) Paine M. F., Criss A. B., Watkins P. B., Drug Metab. Dispos., 32, 1146-1153 (2004).

19) Yamada Y., Drug. Metab. Pharmacokinet., 22, 13-28 (2007). 